\title{
The effects of teaching Eng as a profession on the status of Palestinian-Israeli women
}

\author{
Dina Jazmawi Abu-Obaid, Al-Qasemi \\ Academic College of Education, Baqa al-Gharbiya, Israel \\ Email address: \\ dina_abied@hotmail.com (D.J.Abu-Obaid)
}

To cite this article:

Dina Jazmawi Abu-Obaid, Al-Qasemi. The Effects of Teaching Eng as a Profession on the Status of Palestinian-Israeli Women. Science Journal of Education. Vol. 2, No. 3, 2014, pp. 75-84. doi: 10.11648/j.sjedu.20140203.12

\begin{abstract}
In the Israeli society, English language is considered a prestigious language and a gateway to higher education [26]. The high status accorded to English acquisition by the Israeli community can lead to parental pressure for English instruction at home, and a willingness to pay extra for private lessons to improve proficiency [5]. In this article, I analyze the association between English teaching as a profession and the social status of female Palestinian-Israeli English teachers. In particular, I examine how these English teachers experience their social status in their work contexts and communities, and their profession's relation to economic independence and professional development. The research sample was composed of 12 Palestinian-Israeli women who are English teachers at three schools in the Northern Triangle in Israel. The main tool used in this qualitative research was the semi-structured oral interview. By analyzing the women's talk, I found that being an English teacher played a significant role in raising the social status of the investigated teachers. Additionally, it helped them create a professional identity, and positively affected them economically and psychologically.
\end{abstract}

Keywords: Social Status, Economic Independence, Professional Identity

\section{Introduction}

Languages are symbols of values, people, ideologies, and behaviours[9]. In Israel, the modes of learning Arabic, Hebrew, and English are directly related to the dominance of Hebrew[23] and reflect the socio-political context, the status of and different roles that Israelis and Palestinians play in Israeli society, and the wider political conflict in the Middle East[23]. Consequently, Palestinian-Israelis ${ }^{1}$, comprising $20 \%$ of the Israeli population and whose L1 (first language) is Arabic [23], must learn three languages during their formal education: standard Arabic (used among Arabs speakers internationally); Hebrew (the primary official language of Israel, used in all contexts of public life) [8], and English, the lingua franca of many fields throughout the world. Today, the English language is 'seen as a gateway to higher education and a constant goal of the Israeli society' [26]. As English is accorded such a high status by the Israeli community, there can be parental pressure for English instruction at home, with parents willing to foot the bill for

\footnotetext{
1 There are more than 21 different terms for Palestinians who live in Israel [18], including 'Israeli Arabs', '1948 Arabs', and 'the inside Arabs'.
}

private lessons to improve proficiency so the students may benefit from the advantages of its acquisition [5].

The multilingual Israeli society consists of a number of ethno-linguistic groups. The predominant groups are Hebrew-speaking Jews, Palestinian-Israelis, and Druze, as well as recently arrived immigrants from the former USSR, whose main language is Russian [23].

Sometimes a group needs to acquire a new language for communication, commercial interactions, or social integration purposes. Acquisition of the new language is affected by several factors, including socio-psychological (e.g., attitudes and stereotypes toward the speakers of these languages), ethno-linguistic (e.g., group identity, unity and affiliation), and political (e.g., ideology and conflict)[23].

In this study, I investigated the influence that the important status of the English language has on the investigated women's social culture, economic independence, and professional development. I wanted the English teachers to speak about their own experience in the public sphere in order to see how they experience their social status: How does being English teachers help them gain economic independence? How do they experience their professional development? My focus on the women's experience had two points of departure. First, I firmly 
believe that women should not be marginalised, and their voices should be heard in any field of life. Secondly, women's experiences, feelings, and opinions can be a trustworthy and reliable source of knowledge from which we can promote a better lifestyle.

In this article, I examine the status of women in Palestinian-Israeli society and teaching English affecting it, and relate it to the experiences of the investigated women in my study. My purpose is to contribute to a better understanding of the association between teaching English and the cultural capital of Palestinian-Israeli women, and how being English teachers can elevate their social status in both their community and work contexts.

\section{Theoretical Background}

\subsection{The Importance of the English Language}

Modern English is sometimes described as the world lingua franca, because it is used as a universal means of communication for various domains such as science, technology, and academia. Most scientific conferences take place in English, and many products have a trademark based on English [28].

With English as a predominant language, countries the world over have made English a compulsory subject of instruction. In Israel, it is government policy that English language be a core subject at schools [26]. The relative share of English in the curriculum has increased over the last few years, and this increase is seen as an indication of its importance in the hierarchy of school subjects [6]. In the current Israeli high school system, the curriculum is composed of optional and compulsory subjects. Each subject can be studied at different levels, ranging from one to five units of study. The time devoted to each subject corresponds to the number of units, or level, of the subject matter [6]. English is compulsory at the three-unit level, and to qualify for a matriculation certificate, a student must pass national exams. The universities, however, demand at least one four-unit subject from their candidates, and offer admission point bonuses for each subject taken at the fouror five-unit level [7]. In calculating a student's average from the matriculation certificate, the universities add 10 points to the original score for each four-unit level subject and 20 points to a five-unit level. English gets higher bonuses: 12.5 points for the four-unit level and 25 points for the five-unit level [7]. These bonuses are crucial to the students' scores because of the severe competition among university candidates, particularly in the most popular areas of study [7].

\subsection{Palestinian-Israeli Women and the Labour Market in Israeli Society}

Many factors influence women's employment in Palestinian-Israeli society, including religion, culture, and social status. In Jewish Israeli society, as well, the labour market is not bias-free; it is influenced by ethnicity, gender and religion. The effects on the Palestinian-Israeli woman are compounded by her inequality in both Israeli society and the Palestinian-Israeli community.

In Palestinian-Israeli society, there are religious, cultural, and social perspectives toward women's paid work. According to Islamic precepts, a man should provide a woman with a substantial livelihood, and the role of the woman is to take care of the children, the house, and her husband's needs [2]. Islamic cleric Hassan Albana [2] observes that Islam forbids encounters of mixed gender. The Islamic view is that these encounters pose a real danger to both men and women, encouraging the loss of inhibitions, negative intentions, and the corruption of souls, and leading to the break-up of homes. Islamic cleric Muhammad AlShaa'rawi [3] claims that women's role in the home is nobler than the role of women outside it. While men deal with the mundane matters of the public sphere, women are in charge of the noblest thing in existence, the raising of children.

Culturally and socially, the home is the private sphere of the woman; it is the 'woman's kingdom'. A woman's primary duty is to take care of her house, children, and husband [12].

Societies that oppose a woman's right to work at gainful employment as a human right, and not linked to economic needs, can be seen as fearing changes in the traditional role division between men as providers and women as provided for. These societies fear the potential impact of a transformation of women from beings who should obey their husbands into beings who challenge their subordinate status [15].

In Palestinian-Israeli society, a woman leaving the home to work is not something new; women have always participated in agricultural work, and they shared the work in the fields alongside the men [13]. But they were not paid directly for their labour, because the earnings were shared among the family, and generally it was the men who governed financial matters [13]. Today, as a result of the increasing number of transformations Palestinian-Israeli society has undergone, this has changed. Women have begun to work in paid employment outside of the family, in areas such as educational or health care, in the professions, as doctors, lawyers and engineers, or in office work [13]. Women are also going to work in positions that do not require any professional training or knowledge, such as in agriculture, in the textile industry or in factories[11].

The transformation from unpaid labourer to paid professional is bringing about a change in the community's models of social relations [10]. Women no longer work in the presence and under the supervision of the family. Women now move in different circles, independent of direct family monitoring, giving them more freedom of movement [10]. When women join the work force, there is a collapse of the separation between men and women. With this direct interaction between the sexes, the notion of modesty has begun to undergo change [12].

At present, according to[12], the concept of the woman's 
right to employment enjoys a high level of social legitimacy in Palestinian-Israeli society. There is agreement that women's employment contributes to an improvement of the family's economic situation. Also, employment of women is seen as a tool that offers women independence, creating opportunities to play new social roles in their communities. Ghanem [12] also claims that this social legitimacy does not necessarily express a belief that employment is an unconditional right for women, but rather is a product of need. It is expected that women who earn money will contribute to the family finances.

Women's employment only receives approval and acceptance under certain conditions: the established need to work and the type of work [12]. Men have been accepting of their wives going to work in types of jobs that are considered suitable for women, and not perceived as threatening to the male role of decision maker or power holder in the public sphere. The main social expectation from women is to perform as homemakers: first and foremost, they should be wives and mothers. Palestinian-Israeli society views child rearing as the domain of mothers or other women, and the husband, as an external superior, does not get involved in the children's upbringing or education [12]. Moreover, since the acceptance of the woman's going to work is not associated with the man's readiness to take a more active part in household tasks, working in the public sphere should not lessen this duty. Consequently, women's employment outside the home can become a burden, rather than a means of self-realization [12].

\subsection{Factors in Choosing a Profession}

The choice of profession of Palestinian-Israeli women is determined first by the political conditions in which the Palestinian-Israelis live, and secondly by the social conditions and expectations they must fulfil [11]

The socio-political situation in Israel plays an important role in how Palestinian-Israeli women choose a profession there. The lack of nearby places of employment, or convenient public transportation, the paucity of child day care centres, and the cutbacks in funding for the local Palestinian-Israeli authorities have led to serious obstacles to women entering the labour market [11]. These funding cutbacks to the local Palestinian-Israeli authorities have led to a regional lack of suitable employment opportunities, a lack of public services such as organised transportation from the Palestinian villages to their neighbouring cities, and no provision for the day care centres that could guarantee a secure place for children while the mother is at work [11].

Moreover, the state, considered the main employer for Jewish women, does not offer a similar level of employment for Palestinian women. In Palestinian villages, there are almost no governmental offices or companies able to absorb women into the staff, with the result that the proportion of Palestinian-Israeli women working in the public sector is far lower than the proportion of Jewish women [11]. Thus, Palestinian women are doubly affected by the policies of the Israeli government.

Socially, women finding employment outside the home has become acceptable, but conditional on their ability to subordinate it to their primary duties as homemakers [1]. Their jobs should only require them to be away from home for the least amount of time possible, and not affect the performance of their primary duty, the home. When a woman works outside the home, she does double duty as homemaker and employee. Consequently, women are cautioned to choose work hours that allow them to juggle their responsibilities between their jobs, their homes, their children, and their husbands [1].

Another criterion necessary for jobs considered suitable for women is that they do not threaten men's position as the decision makers and power holders in the public sphere, jobs where women are not decision makers, rather the decisions are made for them [1]. This consideration must be taken into account when choosing a profession. For instance, although working in the field of education is suitable for both men and women, in effect it is being transformed into a profession 'for women' because it satisfies the requirement of balancing home and work, and it does not abrogate male superiority [12]. Thus, based on the social and political conditions in which Palestinian women live, I will examines teaching as a form of independence and source of social respect for them.

\section{Research Method}

This study was based on qualitative research, a field of study that crosscuts disciplines and subject matters, and involves an understanding of human behaviors and the reasons that govern human behavior. It investigates the why and how of decision making [24].

In this study, I valued the investigated women's voices and experiences. I wanted the researched women to talk about their own experiences, using their own words and interpretations. To accomplish this, I used the semi-structured interview. I conducted interviews consisting of open-ended questions that allowed the respondent to talk about her opinions, while I determined the subject and the focus of the interview. Using this kind of interview enabled me to achieve an active involvement of my respondents in the construction of data about their lives[18], achieve a free interaction between me and my interviewees, explore my interviewees' views or reality, ascertain the information that can be compared with information with other interviews, and finally generate a theory [18].

This study was carried out in three distinct PalestinianIsraeli schools in the North Triangle, where English is taught as an L3 (third language) at the elementary, junior high, and high school levels. In these schools the majority of the English teachers are female. Since some female teachers refused to be interviewed, my research study population was 12 female teachers of different age groups. 
In one school, I contacted two groups of female teachers; female English teachers who teach classes at elementary level and female teachers who teach classes at junior high school level. At high school level, I contacted female English teachers teaching in two different schools in two different locations in the North Triangle. I introduced my subject by telling them about my willing to write a final paper needed as a partial requirement in my doctorate studies and 12 teachers from whom informal consent was obtained. Though the investigated teachers teach different levels, I treated them as one group all because they expressed similar opinions and beliefs towards the investigated issues. All the participants in this study are Muslims, as the population of this region does not include any Christian Palestinian-Israelis. ${ }^{2}$ The names of all the participants are pseudonyms. In order to give a good description to how Palestinian women who work as English teachers experience their social status and professional development, and how it helps them gain economic independence, I interviewed four female English teachers from Arara High School, four female English teachers from Um El Fahem Comprehensive High School, and four female English teachers from Maisser Elementary School.

Four female English teachers from Arara High School

The population of Arara is approximately 10,000. Its residents are not considered religiously observant by the wider Palestinian-Israeli community, and its socio-economic status is not strong. There are five schools in the village: one junior high school, three elementary schools, and one high school, at which students can specialise in a variety of science or humanities majors. Both men and women teach various levels of English in the high school.

Four Female English Teachers from Maisser Elementary School.

Maisser's population is about 1,500 . There is only one school in this village, which includes classes from the first grade through the ninth grade. The socio-economic situation in Maisser is strong relative to that of neighbouring villages. The majority of its population either works at various jobs or are salaried employees. The village of Maisser consists of three big families, or hamoolas, which are on friendly terms. Religiously, Maisser's residents are considered 'traditional-modern' by the wider Palestinian-Israeli community. All the English teachers in the school are women.

Four Female English Teachers from Um El Fahem Comprehensive High School.

Um El Fahem has approximately 45,000 residents, most of whom are considered religiously conservative and traditional by the wider Palestinian-Israeli community. Recently, this city has undergone sweeping political,

\footnotetext{
${ }^{2}$ I chose these schools I am originally from Arara village, and now live in Maisser, and teach at Um El Fahem Comprehensive High School, all of which are located in the Northern Triangle. My religious identification is Muslim
}

religious, educational, and economic changes. There are three high schools, one of which is Um El Fahem Comprehensive High School, where there are both male and female teachers. Students can choose either a science or humanities major. English is taught at different levels. All the English teachers are female.

Care was taken to respect and protect the investigated participants' autonomy, rights and dignity throughout the process of the study. All information and records provided by the participants were kept confidential by assigning codes for recording the data. The participants were informed that they had the right to leave the research at any point of time. During the interview, if the participants didn't feel like responding to any particular question, they had the right to say so. The recorded interviews were subsequently erased.

The interviews were conducted and recorded in Arabic, the interviewees' L1, at their homes in the afternoons, as the interviewees' wished. The interviews were "constant without interruption, the thing that helped recording the interviews word by word clearly and effectively" [22]. To record theses interviews, I used a high quality of recording instrument. Recording the interview has released me from the responsibility of writing the content of the interview, and enabled me to listen, watch carefully, and to interact with my interviewees, the thing that affected positively the process of the interviews [22]. After recording the interviews, I transcribed them and then translated them into English. In order to ensure research reliability, I gave the 12 participants the opportunity to read my transcription of their answers.

I used the content analysis tool - a technique for making inferences by objectively and systematically identifying specified characteristics of message [20] - to analyze the findings. The responses to the open questions were used to categorize the investigated participants' descriptions of their teaching experiences. The use of the symbolically loaded words, both deliberately and unconsciously, was taken into consideration during the content analysis.

I found that the interviewees shared their experiences easily. Distinct themes concerning teaching English emerged from repeating ideas in their responses, such as the effect of English teaching as a profession on Palestinian-Israeli social status, financial independence, and professional development.

Since I am an English teacher, my study was shaped in two complementary ways. First, theory-making was based on my personal sensitivity concerning teaching English, self-esteem, and social status. This sharpened my sensitivity while listening to my interviewees-Secondly, the fact that I am an English teacher invoked inter-subjectivity and strengthened the reflexivity process. Because the participants felt that the interviewer shared their experiences rather than merely observing them as a professional, the complex issue of power relations in the research process was not uni-directional [20].

The aim of the interview process was twofold: to 
determine the interviewees' attitudes toward English, and how they thought being English teachers influenced their social status, their economic independence, and their professional development.

As my objectives was following the process of becoming an English teacher and its effect on the social status, I will now present the finding along the line of the process, as I came to understand it from within analysis.

\section{Findings}

Although the patriarchal family in the Palestinian Israeli society has been exposed to a number of transformations, women living in this patriarchal society are still socially treated as subordinated beings and marginalized objects who are totally rely upon men, and whose main role is in the private sphere [12]. English female teachers, however, enjoy much more liberal and higher social status in this society. Teaching English as a profession helped women to elevate their social status both in their community and work places; it enabled them to build their professional self esteem, to be treated as independent respectful individuals, and to gain financial and social independence. In the findings of this research, as Cook found [17], all the participants in the present study expressed positive attitudes toward English teaching. They perceive English as universal language, acquisition of which leads to economic success, social status, and success in life.

Teaching English as a profession influences the Palestinian-Israeli women's social status in different ways. As [28] pointed out, English is a prestigious language, the world lingua franca, because it is used as a universal means of communication for domains such as business, science, technology, sports, politics, academia, international dealings of all kinds, and in the media. I found that all my investigated interviewees believe that the status of English has influenced them. Teaching English as a profession meant a source of a cultural capital, professional development, and financial independence.

\subsection{Cultural Capital}

English language is a tool used by its obtainer to gain access to powerful positions in their society. As a means of education and employment, for getting ahead, the obtaining of English brings with it a higher social status [27]. In Israel, it functions as a gatekeeper to positions of prestige in a society [17].In my study, the command of it and teaching it bestow upon the investigated teachers such a high regard in their society. All of the participants think the important status of the English language raises the status of English teachers, and therefore English teaching becomes a prestigious profession. One of the investigated teachers told me that 'because it [English] is the language of our era, technology and the modern world, teaching English has become important and prestigious'. Another woman stated, 'Teaching English is as important as teaching math. It is a subject that all students, with no exception, must acquire, otherwise they won't get a bagrut [matriculation] certification. Also, it is a language which they need in their daily lives'. Another interviewee stated, 'In my opinion, all the subjects are important, but English is used and needed after completing school because it is an international language, and its acquisition is useful in travelling, shopping, and studying abroad'.

These interviewees clearly depict how both the global status of English as the language of the era, academy, technology and communication, and its local status as a needed language for acquiring matriculation certificate raises the English status; it becomes a prestigious language, and, therefore, uplifts the social status of its obtainers.

The relative share of English in the curriculum has increased over the last few years and this increase is seen as an indication of its importance in the hierarchy of school subjects [6]. All the participants believe that English teachers have higher status than other teachers do. When I asked them whether teaching English is more prestigious than teaching other languages, one of my interviewees said: 'Yes, because it is a difficult subject. Also, there is a policy to strengthen the English teaching [program], and this raises the status of English. All of the teachers and the principal know that English is a crucial subject for continuing in academic studies'. Another interviewee had a similar answer: 'Sure, one hundred per cent. For example, English is a requirement in the universities; without it, you won't be accepted. It's an essential subject'. Being able to teach an essential and difficult subject, as it is illustrated by these interviewees, makes English teachers feel how important they are in their workplace. Teaching English as a crucial subject for resuming academic studies stresses the importance of the role these English teachers play and consequently raises their status at their schools. They think that teaching English is much more prestigious than teaching other languages.

\subsection{Teaching is the Most Suitable Profession for Women}

When a woman works outside the home, she does double duty as both homemaker and employee. Consequently, women are cautioned to choose work hours that allow them to juggle their responsibilities between their jobs, their homes, their children, and their husbands. As Ghanem, [12] found that for The Palestinian Israeli women teaching and nursing are the most suitable and common jobs, all the participants in my study think that teaching English is suitable for women, because it enables them both to perform their jobs as professionals in the public sphere, and their responsibilities as mothers and wives in the home. Moreover, not only did the participants find teaching English as a profession acceptable, they highly recommended it. One of the investigated teachers said: 'They [her parents] always say that this profession is easy and you return home early in the day. [They say] "Don't forget that one day you will get married, and you have to perform your duties as a mother and a housewife. Being a teacher is suitable for this"'. Another teacher stressed this 
point when she said: 'It is more comfortable and suitable for women'. A third teacher also said: 'Teaching is very convenient job. It allows women to perform their traditional work without pressure. There is flexibility. You can coordinate between being a wife, mother, and employee. Besides, it helps you to have an active role in your society and not to be only a wife or a mother who has to take care of her house, husband and children'.

Finally, English teaching is a profession that offers a chance of a better livelihood and modern types of social connection[16]. English teachers not only enjoy the social legitimacy and acceptance to work in the public sphere in a society where women's position and main duty is in the private sphere, they are also admired and thought to be more intellectual, and, therefore, have the opportunity to get married with important people who enjoy high social status. In my research, found that all the participants married educated and wealthy men, and enjoy a prestigious marital life. One of my interviewee's husbands is a businessman, another one's husband is a doctor. The professions of the spouses of others include computer expert, dentist, and engineer.

\subsection{Modernization}

Modernization is sometimes seen as identical to 'westernization' [27]. English language is perceived as a symbol of developed culture. Speaking English may be a criterion for membership in the 'western' sector [27], and its obtainers understood that the acquisition of English make possible improvements in their lives. All the participants believe that English teaching provides them with the opportunities for exposure to the world, more specifically to the developed world. One interviewee said: for example, 'English is a lingua franca. It is a global and universal language, and when you acquire this language, you can learn a lot about different people, about their habits, cultures, and the ways to deal with them'. Another one referred to this point when she said English 'helps me to be exposed to different cultures and to deal with other people. It helps me to communicate successfully with other people who belong to different cultures. It also helps me to know the latest fashions, and to know how women are treated throughout the world. Unlike the majority of the Palestinian-Israeli women, by teaching English, the symbol of modernization, as it is depicted by the interviewees, English female teachers are living much more liberal modern life.

By virtue of their being of English teachers, 'the' language of modernization [16], Palestinian-Israeli women are serving as agents of change in their society. English acquisition is used as a tool to avoid marginality of women, symbolises success, power, will, and a strong desire to reject the oppression and inferiority women face. Being an English teacher enables the investigated teachers to take part in the public sphere. Most of the participants believe that teaching provides them with the opportunity to be creative, and to play an effective role in society. One teacher said: '[The students] need me. Without me, they would have a problem, because it is difficult to find English teachers. So, they always try to make me happy. As a result of teaching English, Palestinian women are treated as central subjects rather than marginalised objects in their workplace. Because of teaching English, they are needed not only in the private sphere but also in the public sphere, and, therefore, are able to play significant roles in their society.

Sometimes a group needs to acquire a new language for communication, commercial interactions, or social integration purposes [23]. English can serve the Palestinian English teachers as means that facilitates and enables them communicate with different people and enable them to use technology. All the participants indicated that English facilitates their lives in this respect. It helps them to be up-to-date, flexible while dealing with different behaviours and people, and it enables them to use technology properly. It also helps them to know the latest international and local events. For instance, one of the investigated teachers said: 'It makes it easier for me to be exposed to the modern world, to understand what is happening around me. It helps me a lot in my travels abroad. It also helps me to be modern and up-to-date in the latest fashion and events'. A research subject who works in Um El Fahem Comprehensive High school, lives in the West Bank, but is originally from Nazereth, said: 'It gives me flexibility. You know there is a cultural, social, political, and economic difference between Nazareth and the West Bank. There is also a significant cultural difference between Nazareth and Um El Fahem...English helps me to know about the causes of these differences and how to deal with them'.

As it is depicted by the interviewees, commanding the English language enabled the Palestinian female English teachers to live more modernised life, to be able to communicate with different people, to be exposed to modern world and different cultures, to up to date in the latest fashion and events, and using the latest technology. Teaching English helped them to make a change and improve their status. They play central roles in both the public and private sphere.

\subsection{Code Switching}

English is perceived as a symbol of open-mindedness, and indicating determination and sociability and speakers insert English into their conversation to demonstrate that they are intelligent [16]. Most of the participants indicated that they use English expressions and words in their speech. They employ code switching for several reasons. First, when they code switch, they, as Amara [4] found for code switching, impress others by demonstrating that they speak an important language that has a high status. They demonstrate to their society that they are modern and identify with the developed world. This influences their social status - others admire them. Secondly, they also use code switching to show that they belong to a certain professional group (English teachers) and have something in common with other members of this group [25], all of 
whom teach a subject with a high status relative to other subjects. One interviewee told me, '[I speak] English and Arabic. When I speak in Arabic I usually use English words'. When asked why, she responded, 'Because by using these words I express myself better, they understand me better, and [I can] impress others'. Another one also said: 'I spontaneously use English expressions and words. Even with my children,.... I also use it with my colleagues, especially English teachers'. The depiction of the interviewees shows that by using English expressions English female teachers impress others, and admired by others. Using English language raises their social status at their schools.

\subsection{Social Independence}

Employment of women is seen as a tool that offers women independence, creating opportunities to play new social roles in their communities Ghanem [12]. Despite the different functions and duties they have to perform and juggle, developing a career and playing an active role in the public sphere in a society that places a lower value on women make the participants feel happy, satisfied and proud of themselves. One of the investigated teachers explained, 'When I teach English, I feel something special. I feel that I play an active role. I do something special that not everybody can do. You know, after this long period studying at different colleges, I finally achieved my purpose. Now I feel satisfied...I feel proud of myself'. This active role helps some of participants to foster and build high self-esteem, strengthen their personalities, and raise their social status, as another investigated English teacher who teaches at Um El Fahem school indicated: 'It helps you to build your personality. It also affects my children's personalities - it encourages them to be independent, because they have a model to imitate,' and 'I believe that if a person is economically independent, this will improve and strengthen their personality'. She continued:

Working in the public sphere helps you to improve your career and ability to do things and to be creative. This way, you won't feel depressed and frustrated. People who work in the public sphere have the chance to meet different people and will renew [said in English] their skills and abilities, energies, capacities, and ability to practice new things. They will have the ability to deal with things inside and outside the house, and will have the ability to deal with different people in different ways.

Another teacher teaching in the same school also stressed the self independence point, when she said: 'I like [emphatically] it very much, because it enables me to be independent and I don't have to rely upon anyone. It helps me to play an active role both in my society and in my family'.

\subsection{Economic Independence}

Being an English teacher helps them to improve their socio economic status. It benefits them economically by helping them find work. The lack of English teachers, especially in the high school level, means that many employment opportunities are available. The findings of this study indicate that the participants considered English teaching a good means of finding employment. All the participants showed that being English teachers enabled them to find teaching positions easily, to be economically independent, and to improve their status both in their family and in society. One of my interviewees explained why she chose the profession of English teaching: 'First, because I love the English language. Second, it was easy to find a job. It is a universal language and it is used a lot. It is an important language for everybody. They need it'. Another interviewee said that being an English teacher 'helps to find a job easily'.

As Tollefson [27] noted, English is one criterion for determining who will continue and complete his academic education in different domains, as it offers opportunities for higher education and a career in public sphere. The data of the present study shows that all the participants noted that they found work immediately after finishing their academic studies.

\subsection{Professional Development and Professional Self-Esteem}

In Israeli society, teaching English is not only a suitable profession for women, however; it also raises their self-esteem [19]. Being an English teacher enables them to take part in the public sphere and to exhibit confidence. For Palestinian women in Israel, English acquisition symbolizes success, power, will, a strong desire to improve the past, and a rejection of the oppression and inferiority they face [16]. Although in the patriarchal Palestinian patriarchal society women's main work and position is in the private sphere and not in the public sphere, in the case of the English women teachers, all the participants in this study were encouraged to choose English teaching as a profession. Many of the teachers said that it was their parents who had encouraged them to become English teachers in the public sphere. One of them even said that because of her husband's social status in society, 'he wanted me to study English and become an English teacher'.

The place of the English language is not as a means of communication but as a means to uplifting the Palestinian Israeli female English teachers; by teaching English they increase their social standing as well as their sense of self -esteem. Tollefson [27] and Narkis [16] claim that being an English teacher helps English obtainers to improve their socioeconomic status. It benefits them economically by helping them find work in teaching English, as well as in other fields, more easily. The findings show that some of the participants believe that choosing teaching English as a profession has provided them with better opportunities to promote their professional self-esteem. All the participants work as both English teachers and class tutors. Some of the participants also teach teacher training (hishtalmut) courses in English. As an answer to whether being an English helps 
her to build her self-esteem and improves her social status, one of my investigated teachers said:

Yes, because it is the language of the era, it is the language of development and communication. Without this language, we can't achieve our needs and goals in other fields. The English language provides us with a lot of opportunities to find work in different fields. Because I am an English teacher, I was allowed to play an administrative role at my school. That is, I run the English centre and I am a class tutor.

Another interviewee has similar roles at her school: she is an English teacher, the school's English coordinator, and a class tutor. She also teaches teacher training (hishtalmut) courses in English. Playing such important roles at school (that are usually played by male teachers) by female English teachers, whose main work is in the public sphere, showed, first, the English teaching as a profession enabled them to promote their professional self-esteem. And, secondly, in the case of the English teachers, work in the public sphere is not perceived as threatening to the male role of the decision maker of power holder the public sphere.

\subsection{Professional Identity within a Professional Group}

There is a connection between the language spoken among members of social group and that group's identity. The professional sub-identity is perceived as a part of a person's identity. Choosing a profession, working in it, and relating to it are accepted as consequences and results created[21]. Some of the participants believe that English language acquisition helps them to construct a special professional identity. They become part of the professional group; they are in the centre and not in the margin; they are accepted, admired, respected and treated as important subjects in their workplaces. One of my interviewees said: 'We are English teachers'. Another also said: 'When I speak in English, I impart an idea about myself, about my professional identity'. A third teacher stressed her professional identity by saying, 'I am an English teacher'. The findings also show that all the participants believe they enjoy special consideration in their society because they are English teachers. All the participants showed that their colleagues and principals treat them respectfully. One said: 'They [the principal and the teachers] accept me as a teacher in their staff, they now respect me'. Another one also said: "[The principal and the teachers treated me] very well, always encouraged me, they respect me'. A third teacher stressed her principal and colleagues' respect and admiration. She said: 'They [the principal and teachers] respect and appreciate me'. Another teacher said: 'They [the principal and teachers] respect me, they treat me as something special, important at school'.

\subsection{Sense of Belonging}

By their accent, vocabulary, and speech patterns, speakers identify themselves and are identifies as members of this or that speech and discourse community. The individual derives personal strength and pride, as well as a sense of social importance, from this membership and from using the same language [14]. In this study, all the participants indicated that there is a cordial relationship among English teachers in their schools. One of my interviewee indicated that her relationship with English teachers is stronger than her relationship with teachers of other subjects when she said: 'My relationship with all of the teachers is good, but my relationship with the English teachers is stronger because we have many things to talk about'. Other participants also stressed this point. According to one, 'It [the relationship with teachers of other subjects] is good, but it is not like my relationship with English teachers'. As Kramch [14]claims for self belonging, this close relationship among English teachers, the strong sense of belonging to the same group, and speaking the same language, enable my interviewees to derive social importance, as well as personal strength and pride,

This close relationship and sense of belonging help them to cooperate with and do things for one another. By teaching English the investigated gain a sense of belonging to and contributing to their professional community. One interviewee said: 'We are friends, they always help and advise me'. Another one also said: 'We [English teachers] help each other'. Common behaviour and linguistic codes strengthen this sense of belonging and enforce the social connections among the group members. Common behaviour and linguistic codes distinct and distinguish the members of the group; people around them treat them as a distinct group whose members share common characteristics and traits. The findings indicate that there are common linguistic and behaviour codes among the English teachers. Though these codes are not accepted in the Palestinian patriarchal conservative society, English teachers are respected and admired. One participant indicated that she believes that English teachers share common traits, such as linguistic codes demonstrated in their speech, and the way they dress and behave. For her, these linguistic and behaviour codes connect the English teachers and enable them to understand each other, to accept each other's behaviour. She said:

I always feel that there is a strong relationship among us... I mean that there is a common thing that connects us. This appears in the way we talk, the way we dress, the way we behave...we understand each other. We sometimes use words that only English teachers understand. Sometimes we talk or behave in a way that is not acceptable... I mean in a way that the rest of the teachers who teach other subjects don't accept.

Another interviewee also said: 'I think to some extent we share the same ideas and opinions. We have a common language, there is a similarity in our behaviour, in the way we dress, the way we talk'. 


\section{Discussion}

In this article, I explored the association between teaching English and the social status of the Palestinian woman who works as an English teacher. I examined the social processes in which Palestinian-Israeli women who work as English teachers raise their social status, gain economic independence and professional development. Tollefson[27] suggests that English language is a tool used by its obtainers to gain access to powerful positions in their society. As a means of education and employment, for getting ahead, the obtaining of English brings with it a higher social status. In this sense, on the bases of my interviewees' descriptions, being an English teacher positively influences their social status, and helps them gain economic independence and professional development.

In the Palestinian patriarchal society, women are considered socially inferior and are marginalized objects who totally rely upon men [12]. Command of the English language and teaching it is a way for Palestinian teachers to gain a higher regard and hence higher social capital in their society. Respected by their society and treated differently, they have better opportunities to achieve higher status and a desirable social life (e.g., to marry someone educated and wealthy, as we saw in this study). They are allowed to behave differently and to have their own behaviour and speech code, which appears in their talk, dress, and behaviour, and they have better opportunities to achieve higher status and to build their self-esteem (e.g., to play an administrative role in their schools).

In this study, it was seen that being English teachers enabled the participants to develop a professional identity by which they share common feelings, ideas, and friendship. They have constructed a professional group that shares behaviour and linguistic codes. They use the English language as a unifying factor, a symbol of professional identity, and a powerful resource of solidarity. They tend to use code switching with one another, interspersing their speech with English words and phrases, as a way of expressing their group identity and solidarity.

The perception of English as a symbol of Western culture and modernization also plays a role[27]. Palestinian-Israeli society, as a part of the larger Arab society, is seen as primitive and undemocratic [12]. English, as a symbol of modernization, is perceived as the vehicle through which Palestinian-Israeli society may elicit change, and by mastering it, it would be possible to improve their daily lives [12]. The investigated English teachers used their profession as a means to undermine and reject the traditional view of women in their society, and be perceived as modern women in the modern world. Moreover, because of its role in critical domains such as science and economy, the investigated English teachers whose linguistic and behaviour codes mostly don't go in accordance with the principles and tradition of the Palestinian-Israeli patriarchal society, are treated with respect and admired because socially they are perceived as being intelligent and highly literate individuals.

In Israel, one cannot attend university without competence in English. This influences the economic status of English teachers, as due to the lack of qualified English teachers, especially at the high school level, there are many job opportunities available and all of the investigated teachers easily found employment.

This powerful sense of professional identity, and the values carried by the English language, has had an effect on how the study participants relate to Palestinian-Israeli society. These women experience both a perceived negative political affiliation because they belong to the Palestinian minority in Israel on the one hand, and a perceived negative gender affiliation because they are women who are treated as 'subordinate beings' and repressed by their husbands in Palestinian-Israeli society on the other hand. Working as English teachers, with the social cachet that is attached to the profession, enables them to loosen the bonds of negative affiliation and repression in Israeli society, and men's dominance and repression in Palestinian society.

The greatest improvement that teaching English as a profession has had on the investigated teachers is in their sense of self-esteem, both personal and professional. By having obtained and now teaching English, the lives of the Palestinian-Israeli women English teachers investigated in this study have demonstrably improved.

Due to its prestigious status and practical importance, the investigated English teachers are able to reach administrative positions at their schools, such as coordinator of the English program or program for gifted students. Although the low regard accorded to women in the Palestinian- Israeli society, they are allowed to play administrative roles because their skills are needed. Being valued for their professional skills in turn raises their personal sense of self-esteem. The teachers feel socially confident because they work in the public sphere. Because they earn salaries, they wield more economic power. Speaking English allows them to avoid speaking Hebrew, the language of the dominant Israeli culture. Finally, teaching a English language gains them cultural capital in their society, which allows them to fulfil important roles in their society, and to advance socially and economically into positions of power.

An important point highlighted in this study is that perseverance, a strong will, and self-confidence can enable a woman to overcome her inferior status in Palestinian-Israeli society. By being economically independent, she decreases her reliance on her husband and bolsters her position in society. The English teachers in my study have self-confidence, strong personalities, and the power to challenge the existing traditional values in the traditional Palestinian-Israeli patriarchal-hierarchal society. They enjoy their role in their society.

The implications that emerge from this study can be used in order to raise awareness among women that economic independence is an important factor in obtaining a 
successful future life with high status and self-esteem. Also, women should be made aware that working in the public sphere can decrease male dominance and a woman's reliance upon men. This in turn can limit and decrease the social injustice women suffer. Women should be aware of the importance of education in achieving the cultural capital necessary to work in the public sphere, thereby promoting their status and overcoming a sense of inferiority. In order to be able to determine their own affairs, young women should be motivated to learn prestigious subjects that can raise their cultural capital. Programs should be implemented in which students can experience the feeling of being an equal in society, thus motivating them to work hard to achieve higher status. Future research is needed in order to explore the specific aspects of the cultural capital, professional development, and the economic independence that emerged in my study.

\section{References}

[1] Ahmad, L. (1992). Women and gender in Islam: Historical roots of a modern debate. New Haven: Yale University Press.

[2] Albana, H. (1994). The Muslim woman. (Arabic). Cairo: Al Sona Library.

[3] Alshaa'rawi, M. (1999). The principles of the Muslim house and family. (Arabic). Cairo: Maktabat Al Torath Al Eslami.

[4] Amara, M. (1986). The integration of Hebrew and English into the Arabic spoken in an Arabic village in Israel. (MA thesis, Bar-Ilan University). Tel Aviv: Bar-Ilan University.

[5] Amara, M., \& Mer'i, A. (1999). Issues in linguistic education policy in Arab schools in Israel. (Hebrew). Israel: Givat Haviva.

[6] Ayalon, H. (1995). Math as a grade keeper: Ethnic and gender inequality in course taking of the sciences in Israel. American Journal of Education, 104, 34-65.

[7] Ayalon, H., \& Yogev, A. (1997). Students, school and enrollment in science and humanities courses in Israel secondary education. Educational and Policy Analysis, 19, 339-353.

[8] Azar, H. (2004). Multi-culturalism in society and school. (Hebrew). Israel: The Open University.

[9] Baradac, J.J. (1993). Power in language: Verbal communication and social influence. United States of America: Sage Publications Inc.

[10] Barham, A. (1998). The Arab woman's status as work. In A. Maor (Ed.), Women, increasing power, women's advances at work breaking the 'glass ceiling'.

[11] Elhaj', M. (1996). Education and social consideration among Arabs in Israel. (Hebrew). Tel-Aviv: The International Peace Center in the Middle East.

[12] Ghanem, H. (2005). Attitudes toward the status and rights of
Palestinian women in Israel. (Hebrew). Nazareth, Israel: Women Against Violence.

[13] Ibrahim, A. (1998). The Arab woman at work. In A. Maor (Ed.), Women, increasing power, women's advances at work breaking the 'glass ceiling'. (Hebrew). Israel: Hapoalim Library.

[14] Kramsch, C. (1998). Language and cultural identity. Oxford: University Press.

[15] Mernissi, F. (1996). Women's rebellion and Islamic memory. London: Zed Books.

[16] Narkiss, D. (2002). English in foreign eyes. Theory and Criticism, 20, 259-281.

[17] Pennycook, A. (1994). The cultural politics of English as an international language. London and New York: Longman.

[18] Rabinowitz, D. (1993). Oriental nostalgia: the transformation of the Palestinians into 'Israeli Arabs'. Theory and Criticism, $4,141-152$.

[19] Rozenberg, M., Munk, M., \& Keinan, A. (2002). The choice of the teaching profession and introduction into the profession as a part of the development of self-identity. Dapim, 35, 54-72.

[20] Sabar, N. (2001). Genres and tradition in qualitative research. Israel: Dvir.

[21] Schoenberg, S. (2003). Disciplinary power and the ethics of the self in school: On Foucault's contribution to the art of educational thought. (Hebrew). Theory and Criticism, 22, 133-158.

[22] Shkedi, A. (2010). Words of meaning: qualitative research: Theory and practice. Tel Aviv University: Ramot

[23] Shohamy E., \& Donitsa-Schmidt, S. (1998). Jews vs. Arabs: Language attitudes and stereotypes. Israel: Tel-Aviv University.

[24] Silverman, D. (Ed.) (1998). Qualitative research: Theory, method and practice. London: Sage Publications.

[25] Spolsky, B. (1998). Sociolinguistics. Oxford: Oxford University Press.

[26] Spolsky, B., \& Shohamy, E. (1999). The language of Israel: Policy, ideology and practice. Great Britain: The Cromwell Press Ltd.

[27] Tollefson, J.W. (1994). Planning language, planning inequality: Language policy in the community. London and New York: Longman.

[28] Walters, J. (2007). Why is English the international lingua franca? Available: http://www.translationdirectory.com/article171.htm. (2007, April 9)

[29] http://www.sociology.org.uk/methfi.pdf. (2007, October 20)

[30] http://psychologytoday.com/articles/htms (2007 November 30)

[31] http://links.Justor.org. (2007, December 20). 